\title{
The Application of Modern Diagnostic Systems on Machine and Electric Power Plants
}

\author{
NIKOLA P. ŽEGARAC, Serbian Academy of Inventors \\ and Scientists, Belgrade
}

\author{
Previous announcement \\ UDC: $621-7$
}

DOI: 10.5937/tehnika1901073Z

\begin{abstract}
The paper presents the application of modern diagnostic systems on machine and electric power plants, with special emphasis and experience in applying a new method of maintaining the system and preventing failure, improper operation and system failure. End-users are offered wide-ranging application of diagnostic systems, which function on the principle of OFF-LINE or ON-LINE monitoring systems. The application of new systems allows users to ensure proper operation during plant exploitation. Significantly increases the reliability of the systems. Large savings are achieved in the costs of maintenance and exploitation of the plants.
\end{abstract}

Key words: modern diagnostic systems, monitoring systems, electronics machine plants, electrical installations, diagnostic methods and parameters.

\section{INTRODUCTION}

Modern diagnostic systems have wide application capabilities on machine and electric power plants. They are applied to: hydroelectric power plants, thermal power plants, gas turbines, turbine systems in the process industry, internal combustion engines used as basic plants in many systems, aviation industry, shipbuilding, piston compressors, cement plants, and machine tools. The field of technical diagnostics is a new challenge for many scientists. From a scientific point of view, the state of the technical systems on which diagnostic systems are applied is defined by a set of diagnostic parameters, the conclusion of which is based on the technical correctness of the system. These parameters are the TECHNICAL SYSTEM PARAMETERS. The state of the technical system in the cancellation means that it is necessary to take measures to return the system to a technically correct state: to make certain repairs and replacements of defective circuits or damaged parts. End users are offered complete solutions for the installation of new diagnostic systems on plants, devices and equipment, which is in the process of production, which significantly facilitates application in further exploitation or partial dismantl-

Author's address: Nikola Žegarac, Serbian Academy of Inventors and Scientists, Zemun, Bosanske krajine 22

e-mail: nikolazegarac@vektor.net

Paper received: 20.11.2018.

Paper accepted: 13.01.2019. ing of the system (minimum installation costs) in order to carry out modernization and installation new systems for monitoring and monitoring the technical correctness of existing devices and equipment - monitoring systems. Monitoring systems enable quick and reliable measurement and monitoring of operating and functional parameters of the system in order to increase reliability during exploitation, preventive maintenance, prevention of possible damage, failure and delays in operation, and significant reduction of maintenance costs of the plants.

\section{TYPES AND METHODS OF APPLICATION OF DIAGNOSTIC SYSTEMS}

Depending on the type of plant and its purpose, two MONITORING SYSTEMS concepts are applied, which include various diagnostic systems (devices and equipment), diagnostic parameters and methods and appropriate software for diagnosing the technical condition of the system:

- ON-LINE MONITORING SYSTEMS - are used for continuous measurement and analysis of the technical correctness of the systems. Measuring sensors and monitoring systems are installed on mechanical and electrical installations.

- OFF-LINE MONITORING SYSTEMS - designed for periodic measurements and analysis of the technical condition of the plants. Some sensors are permanently installed in an existing system on a plant in dependence that measures the size of the 
measurement and other sensors are placed along with the permeable part of the monitoring systems when measuring.

Monitoring systems can be used for remote control and monitoring, which is very convenient when system monitoring and technical safety determination is carried out without the presence of the crew.

Special advantage and economic justification for the application of new monitoring systems are large propulsion systems, such as: marine engines, engines used in armored military vehicles (tanks, conveyors and towers), construction machines, rods for oil drilling, electric aggregates that have automation to monitor functional parameters, but do not have the option to control the wear of sliding bearings in order to protect the whole system.

Many systems work without the presence of the crew so that in the event of damage to the plants, damage can be significant.

This paper presents modern monitoring systems on mechanical electrical systems. Due to the scope of work, important diagnostic methods and parameters, which present the correctness of the plant, will be described.

\section{APPLICATION OF MODERN MONITORING SYSTEMS ON INTERNAL COMBUSTION ENGINES USED AS MAIN DRIVES OF VARIOUS TYPES OF PLANTS}

Monitoring systems include diagnostic methods and parameters in order to review the correctness of the plant. These include automatic data acquisition, processing, storing, displaying and using for technical diagnostics, protection and automatic control systems, with the ability to shut down the system if the measured size of the diagnostic parameters exceeds the limits of the allowed values. Such possibilities are provided by ON-LINE monitoring systems.

Monitoring systems include monitoring of various parameters and sizes that fully define the state of the object and its availability for use.

Monitoring systems have the primary task of preparing all relevant data for the correct diagnosis of the technical condition of the plant [1]. The monitoring parameters of the systems are the dimensions that are related to the structural parameters: vibration, temperature, bearing gap - bearing wear, oil pressure in the lubrication system and many other measuring sizes. Measured values are indications of the technical condition of the systems.

The vibration parameters give the most information about the system's technical correctness. In addition to these parameters, the values of other parameters are very important: temperatures at certain measuring points, noise, current parameters, pressure parameters and oil temperature for lubrication, etc. Many diagnostic methods are used in rotary plants, and the method to be applied depends on the type and complexity of the plant, with the economic justification of the investment.

Internal combustion engines are the main propulsion system of various systems and can cause many disruptions in operation. It is meant to mean:

- characteristics of the consumer - a driven device, can be a motor vehicle, a construction machine, a tractor, a generator, a pump, a boat, etc.

- power transmission system,

- auxiliary devices - engine equipment,

- conditions in the engine compartment,

- elastic suspension of the engine,

- modes and conditions for engine exploitation, etc.

It is very important that the correct way of handling and using the engines is internal combustion: cold start, motors with a pre-engine oil pre-lubrication system prior to starting the engine (high-power motors - tank engines), turbocharger engines, user ability to handle systems and to pay attention to proper engine operation, to evaluate whether the combustion is in the engine, the exhaust emission, the correctness of the fuel system, the fuel quality, the coolant temperature, the quality and pressure of the oil for lubrication, the suction of the suction air in the turbocharging system and similar.

The development of the New Common Fuel Feed System has enabled higher engine power, simultaneously increasing the engine's thermal values, and therefore more stringent requirements in the engine cooling system. Systems are particularly sensitive to the quality of propellant. The big problem is the impurities in the fuel, the presence of water and other unauthorized components. This causes damage to parts in the fuel system, the replacement of which is very expensive. It is particularly important that the system user complies with all maintenance standards prescribed for each type of internal combustion engine. Famous world manufacturers of internal combustion engines $(\mathrm{Cu}-$ mmins, Perkins, Volvo, Mercedes, MTU, MWM, DUTZ, Mitsubishi etc.) have developed monitoring systems for their production. Systems have been developed so called. Engine Modul Menagment, which monitors and regulates all motor parameters. Figure 1 shows the Quick Check QC 5200 (handeld computer) monitoring system, the American company Cummins [2].

Modern monitoring systems for internal combustion engines have the functions of monitoring the temperature and pressure of the oil at certain points in the engine lubrication system. They do not have a 
monitoring system for sliding bearing diagnostics, which is very important for further engine exploration. This has been confirmed countless times in engine exploitation.

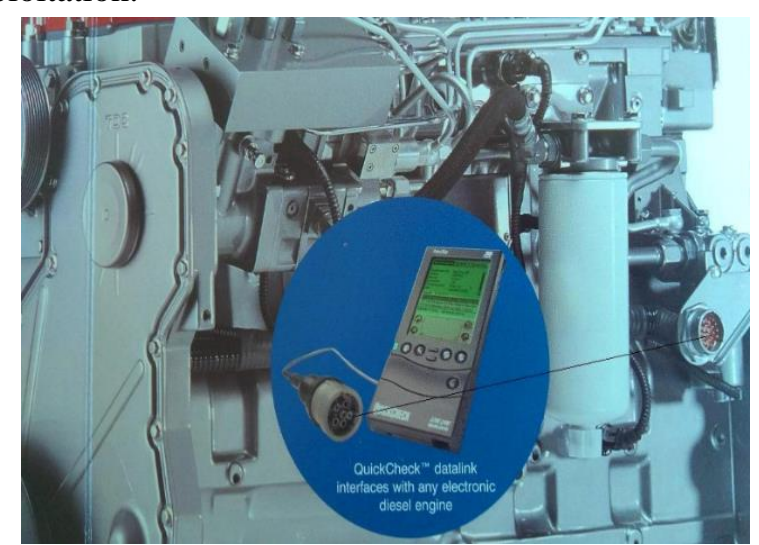

Figure 1 - Quick Check QC 5200 on the diesel engine of the American manufacturer Cummins

The author of the paper cites an example of damage and repair of one sliding bearing on the crankshaft of the engine, on the largest diesel power plant of 2 MW, in the area of Vojvodina. The manufacturer of the aggregate is Mitsubishi - Japan. The plant was installed in the 1950s at a time when there were no modern monitoring systems. Only basic instruments for measuring the operating parameters of diesel electroaggregate were installed in the system. With numerous problems, the user has replaced the sliding bearing, as there is the possibility of replacing the bearing on the engine to remove only the covers on the engine block, without greatly disassembling the engine. About the machining of the crankshaft, the user could not even think about it. It was not possible to do this in our countries, even in the surrounding countries. The big question is that the manufacturer of the system could do it, as it is an obsolete engine production. Nevertheless, this problem has been successfully solved based on the knowledge and rich experience of our experts from Serbia.

The author of this paper has carried out the research and development of a new monitoringg system for sliding bearings for all types of mechanical and electrical installations. The ultimate user is offered a complete solution for monitoring the plants without disassembling, only in some cases, partial disassembly is necessary for the installation of the monitoring system [3].

The research and development of the new monitoring system was carried out on the diesel diesel engines of the renowned manufacturers SulzerSwitzerland and Pielstick - France, in the factory of diesel engines Jugoturbina - Karlovac and Uljanik Pula diesel engine factory - Croatia, which had a license for the production of engines. On these types of engines, installation of monitoring system of sliding bearings was performed.
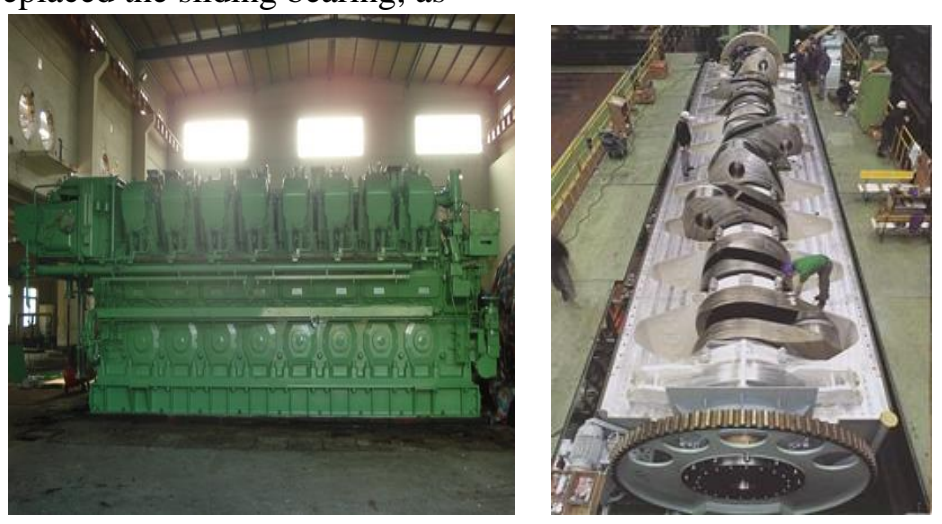

Figure 2 - Display of the ship engine and crankshaft of the Swiss company Sulzer

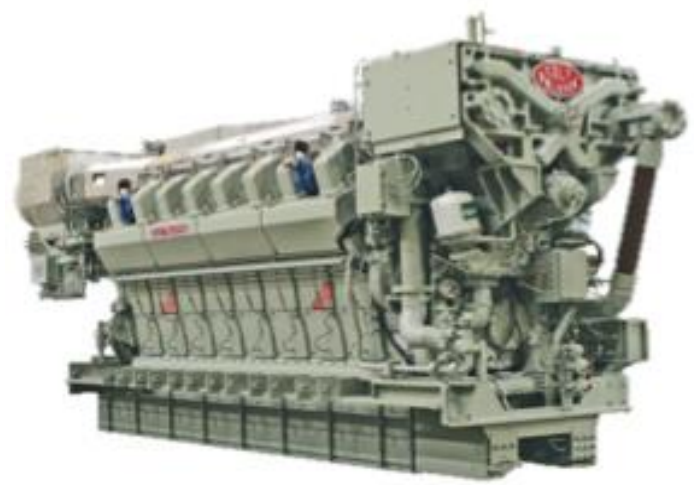

Figure 3 - Display of the ship diesel engine of the French company SEMT Pielstick 
Figure 4 shows the layout of the measuring points on the four-stroke 6ASL-25D. Research on the possibility of diagnostics of the crankshaft bearing displacement of the engine was carried out. Modern methods of dianostasis, measurement of dynamic issues of main bearing sleeves in the main sleeve-bearing bearing, and the influence of bearing wear on the interior and exterior surfaces of the engine have been developed.

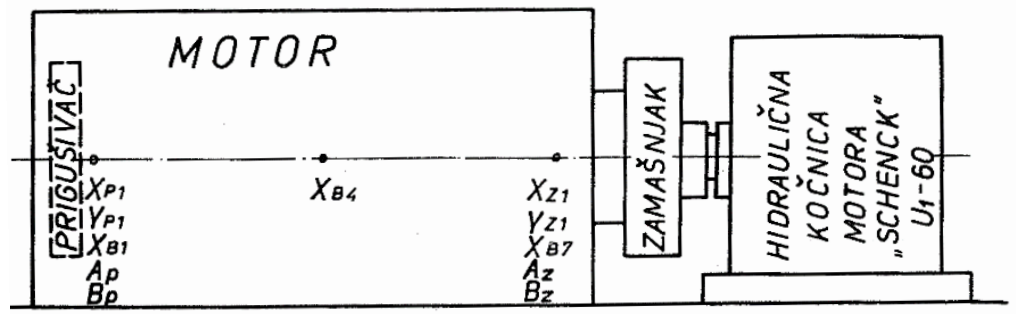

$X_{p 1}$-Vibration measurement on the 1st basic bearing, horizontal direction,

$Y_{p 1}$-Vibration measurement on the 1st basic bearing, vertical direction,

$X_{b 1}$-Vibration measurement on the side bolt of the 1 st basic bearing, horizontal direction,

$A p, B b$ - measurement of dynamics orbits on the 1st basic bearing, direction of the probes $A p, B p$,

$X_{b 4}$ - vibration measurement on the side bolt of the 4th basic bearing, horizontal direction,

$X_{z 1}$-Vibration measurement on the 7 th basic plate, horizontal direction,

$Y_{z 1}$-Vibration measurement on the 7th basic bearing, vertical direction,

$X_{b 7}-$ Measurement of vibrations on the side bolt of the 7th basic bearing, horizontal direction,

$A z, B z$ - measurement of dynamic orbits on the 7 th basic bearing, direction of the probes $A z, B z$

Figure 4 - Measuring position on the engine 6 ASL-25 D, manufacturer Sulzer-Switzerland

Figure 5 shows the monitoring system for the removal of sliding bearings using the new diagnostic method based on measuring the dynamic orbit of the sleeve in the sliding bearing on internal combustion engines [6].
The functionality check and verification of the monitoring system was performed based on the development of dynamic models of internal combustion engine and calculation of the dynamic orbits of the main gears in the engine crankshaft system.

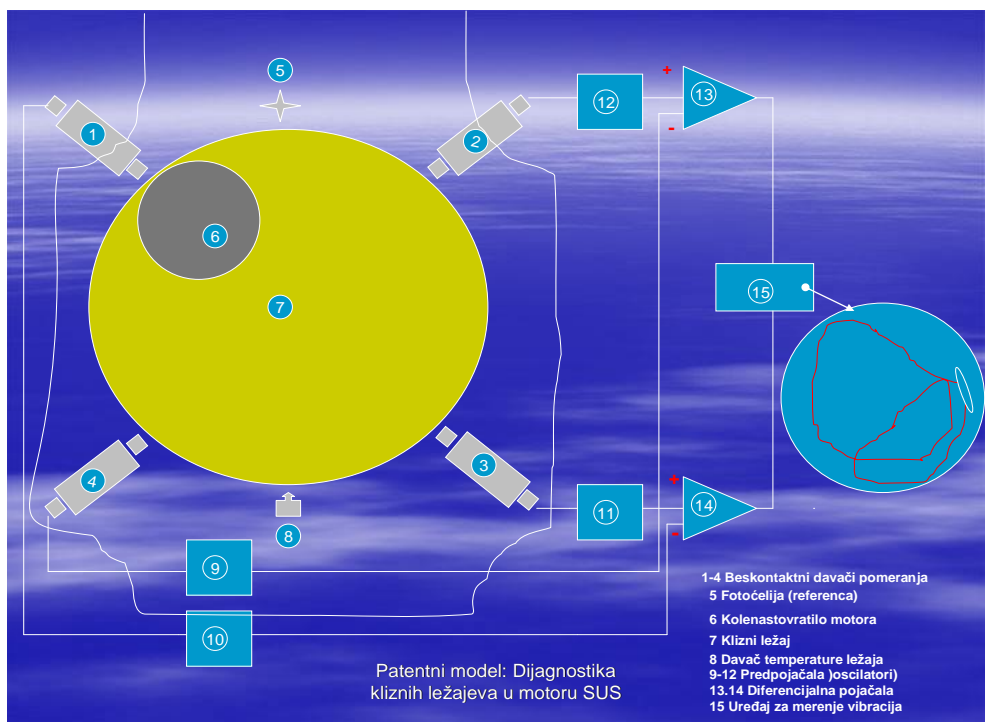

Figure 5 - Display of the monitoring system of sliding bearings

The dynamic orbit of the main sleeve in the sliding bearing represents a new diagnostic method for determining the degree of wear of the sliding bearing. Increasing the gap in the sliding bearing changes the dynamic orbit parameters.

The radial clearance of the bearing to be determined is defined as Fq. (1):

$$
Z=R-r
$$

where the mark: $\mathrm{R}$ - indicates the inner radius of the bearing, $r$ - indicates the outer radius of the bearing sleeve. In the case where the points of the center of the bearing and the center of the sleeve match, the maximum radial clearance in the bearing occurs. In the case 
of a fitting of the sleeve on the surface of the sliding bearing, the value of the radial gap is $\mathrm{Z}=0(\mu \mathrm{m})$.

In computational models of dynamic orbits, the size of the gap in the bearing is defined, $\varepsilon$ - which denotes the relative bearing eccentricity Fq. (2):

$$
\varepsilon=e / Z \text { (2) }
$$

Mark $e$ - indicates the eccentricity of the sleeve, this practically represents the size of the center of the sleeve from the center of the bearing. In the case of the size $e=Z$, then the value of $\varepsilon=1$, which means that the glove touches the bearing surface. In diagnostic procedures these are very unfavorable cases, then there is a dry friction of the sleeve in the bearing and the inevitable damage of the engine lubrication system (damage bearing).

On the graphic representations of the calculated and measured dynamic orbits, the angle of rotation of the crankshaft motor is $\alpha=0^{\circ}$ to 720 , since it is a fourstroke engine.

The angle of rotation of the crankshaft shaft motor $\alpha=0$, indicates the start of the expansion stroke, followed by engine strokes: blowing out, suctioning and completing the compression stroke in the engine when $\alpha=720^{\circ}$, since it is a four-stroke engine. In the graphic representations of the measured dynamic orbits, several cycles of the engine's operation are shown (family of curves and cycle of engine ope-ration). An excellent repeatability of the measurement results can be noticed in the display. The thickness of the oil film during engine operation, which ranges from 15 to $30(\mu \mathrm{m})$, was measured, indicating that there was no risk of scratching the bearing. According to some scientists, the minimum thickness of the oil film for reliable engine operation should be $5(\mu \mathrm{m})$, [7]. Calculating the dynamic orbit issues of the main sleeves requires a very precise modeling of internal combustion engines. Measuring the dynamic orbits of the gloves, belongs to a group of very precise measurements.

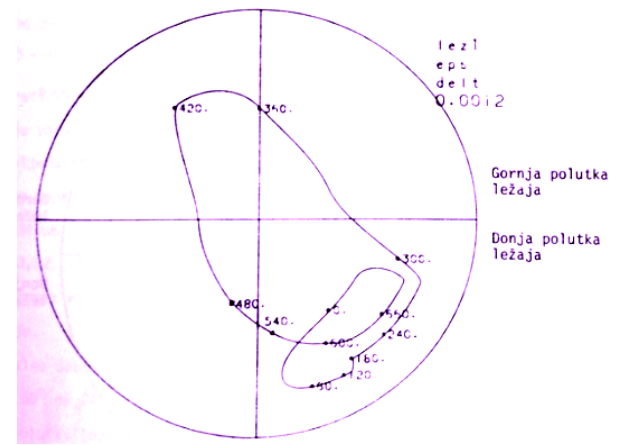

Figure 6 - Shows the calculated dynamic orbit of the main sleeve on the 1st basic bearing crankshaft of the engine crankshaft

The difference in the radial velocity sizes in the tested engine type in the case of a new engine and a radial bearing gap when the engine needs to be generally overhauled, when the bearings need to be changed at the request of the engine manufacturer, is $\Delta Z=60(\mu \mathrm{m})$. So, it's about invisible sizes for the human eye. The author of the patent is working on the development and implementation of another project that would enable the measurement of the wear of the bearings before starting the plant (in a state of rest) [8].

The new system would significantly simplify the monitoring system that is now used when the system is in operation.

Figure 6 shows the calculated dynamic orbit (trajectory) of the main sleeve on the first crankshaft bearing of the internal combustion engine for operating modes: engine load $100 \%$, bearing clearance $Z=124(\mu \mathrm{m})$, engine speed $\mathrm{n}=720\left(\mathrm{~min}^{-1}\right)$.

Figure 7, 8 shows the measured dynamic orbits of the main sleeve on the 1 st basic bearing of the crankshaft engine for different engine operating modes.

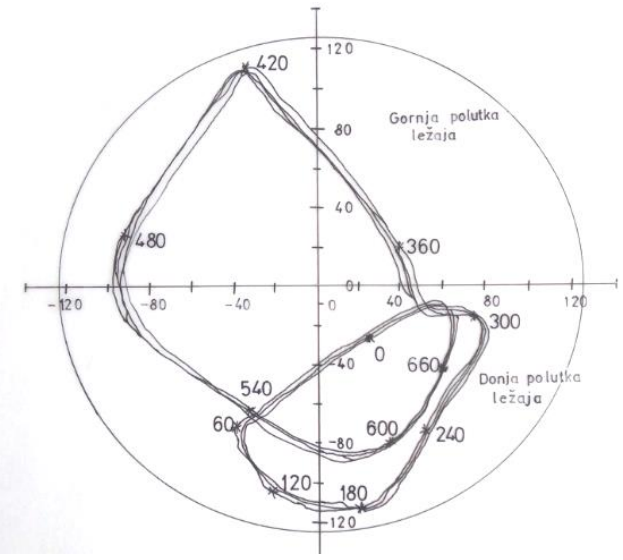

Figure 7 - Shows the measured dynamic orbit of the main sleeve on the 1st basic bearing of the crankshaft engine, the engine load 100\%, $n=720\left(\mathrm{~min}^{-1}\right)$, bearing clearance $Z=124(\mu \mathrm{m})$

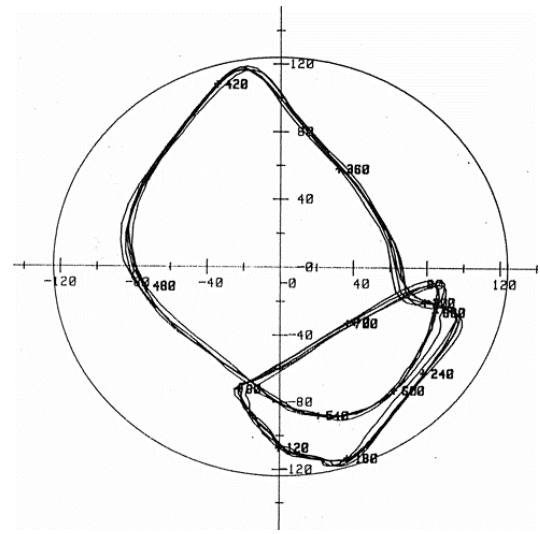

Figure 8 - Measurement of the measured dynamic orbit of the main sleeve on the 1st basic bearing of the crankshaft engine, the engine load $85 \%$, engine speed $n=682\left(\mathrm{~min}^{-1}\right)$, bearing clearance $Z=124(\mu \mathrm{m})$ 


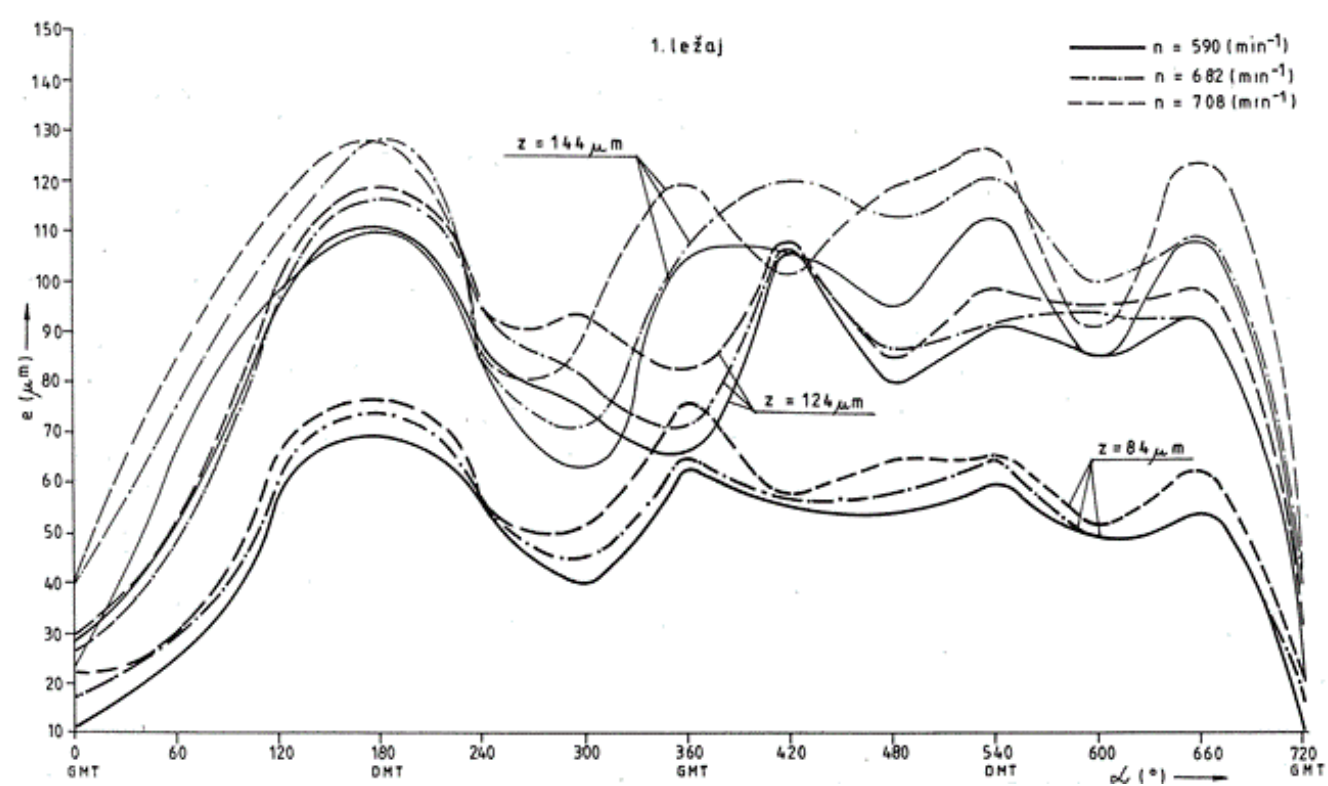

Figure 9 - Measurement of the measured eccentricity of the sleeve on the 1st basic bearing, depending on the angle $(\alpha)$, of rotation of the crankshaft $(\alpha)$, for variations in the size of the gap $Z=84(\mu \mathrm{m}), Z=124(\mu \mathrm{m})$,

$Z=144(\mu \mathrm{m})$ and speeds, withoutengine load

Figure 9 shows an example of the measured eccentricity of the sleeve on the 1 st basic bearing, depending on the angle of rotation of the crankshaft $(\alpha)$ for the gap variations $\mathrm{Z}=84(\mu \mathrm{m}), \quad \mathrm{Z}=124 \quad(\mu \mathrm{m})$, $\mathrm{Z}=144(\mu \mathrm{m})$ and speeds, without engine load.Figure 10

shows an example of the measured calculated sizes of the eccentricity of the sleeve on the 1st basic bearing, depending on the angle of rotation of the crankshaft $(\alpha)$ for variations in the gap size $Z=84(\mu \mathrm{m}), Z=124(\mu \mathrm{m})$, $\mathrm{Z}=144(\mu \mathrm{m})$ and speeds, engine load $100 \%$.

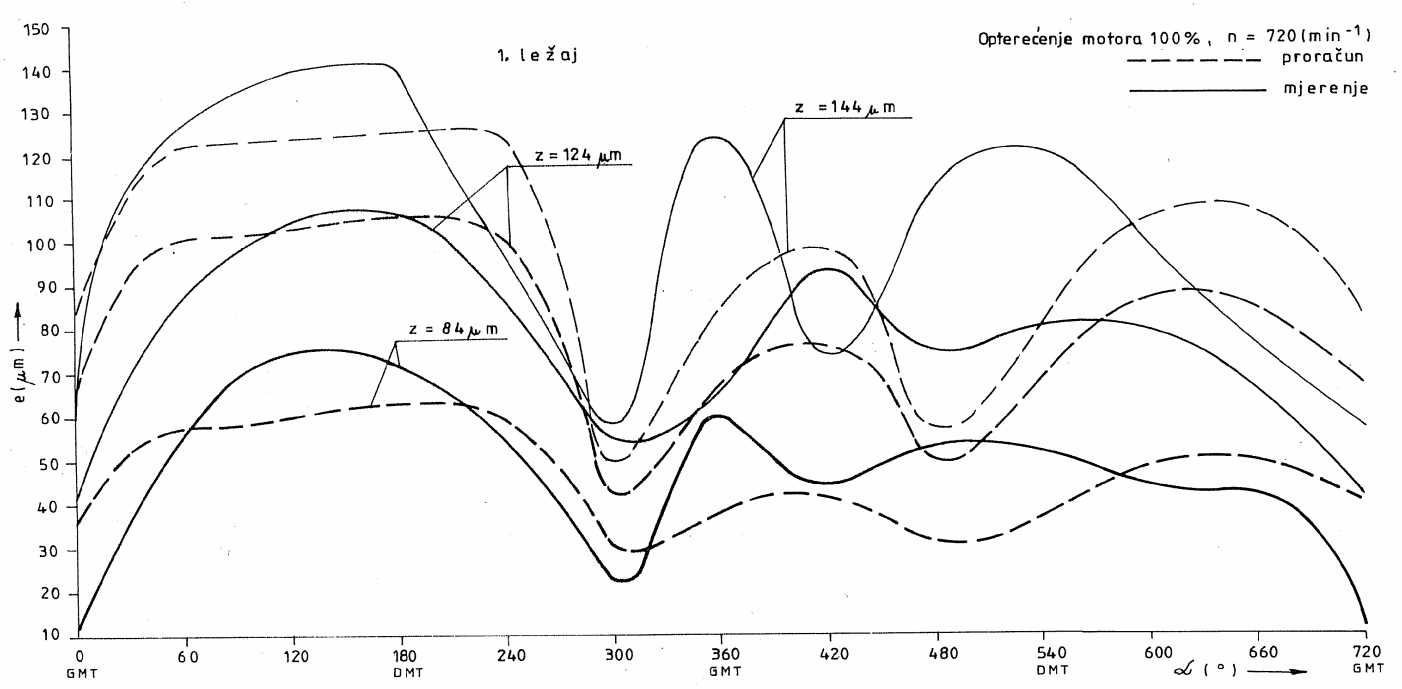

Figure 10 - Display of the measured eccentricity of the sleeve on the 1st basic bearing, depending on the angle of rotation of the crankshaft $(\alpha)$ for variations in the size of the gap $Z=84(\mu \mathrm{m}), Z=124(\mu \mathrm{m}), Z=144$ ( $\mu \mathrm{m})$ and speeds, engine load 100\%

Figure 11 gives a graphical presentation of the bearing hinge eccentricity, depending on the angle of rotation of the crankshaft, at different speeds of rotation and engine loads, based on which the wear of the bearing according to the mathematical formula is reliably determined Fq. (3) [6] :

$$
Z=1.01 e+7.48 \pm s
$$

Where the mark: $s$ - indicates the standard divination, for this type of engine it is $s= \pm 4$. The correlation between the calculated values and the measured values of the parameters of dynamic issues is within the limits of up to $5 \%$.

The monitoring of the sliding bearings system includes the measurement of vibration parameters on the interior and exterior surfaces of the engine [6]. 


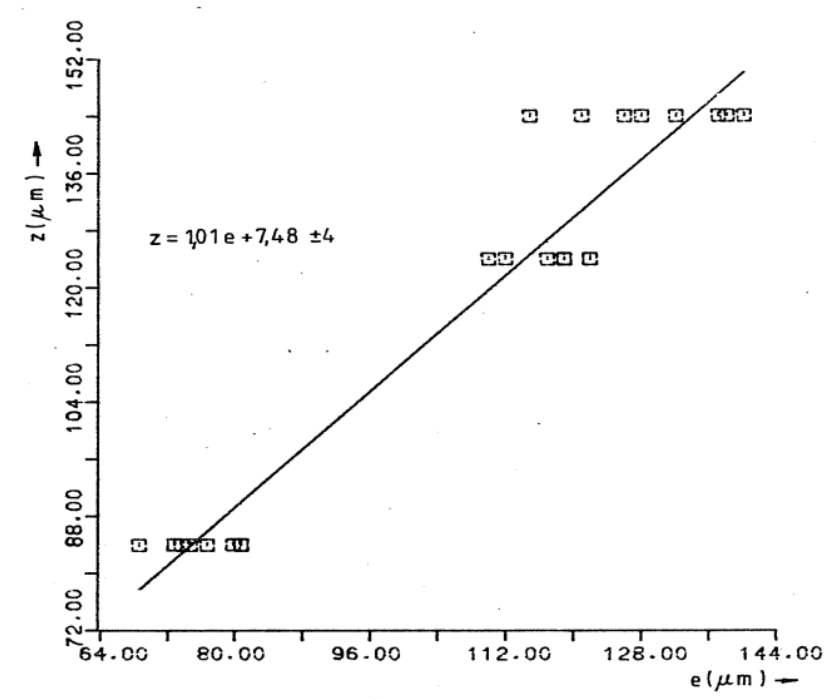

Figure 11-Display of bearing gap (Z), eccentricity (e) size at different speeds of rotation and engine load

Figure 12 shows the measurement results at 7 measuring points depending on the engine speed $n$ ( $\mathrm{min}$ ${ }^{1}$ ), in case the radial clearance of the bearing is at the limit of the allowed values $\mathrm{Z}=144(\mu \mathrm{m})$. The values of vibration parameters, 1-harmonics, effective vibration velocity Vef $(\mathrm{mm} / \mathrm{s})$ are shown, which is most pronounced. To a lesser extent, 0.5-line harmonic is also expressed. At the measuring point 1,2 a measurement on the bottom cover of the casing housing of the crankshaft was carried out. The lid is fixed to the engine block with 2 vertical screws and 2 lateral screws in the horizontal plane of the bearing itself. The measurement results show that there are no significant changes in the vibration level. The reason is that the bearing cover is a very rigid part and the vibrations are not transmitted in the horizontal and vertical directions to the surfaces of the driving forces acting on the motor.

The measurement was performed at the measuring point 3, on the side bolt of the first bearing, in the horizontal plane of the engine. Significant changes in the vibration level were measured. At this point inside the engine casing, there are chambers (circuits) for circulating the coolant fluid, engines that perfectly transmit vibrations to the outer surface of the engine. A similar phenomenon was also found on the side bolts of the engine crankshaft bearing 4 th and 7 th axis.

The vibration levels on the bottom cover of the 7 th basic bearing are extremely small, the same case as on the lower lid of the first crankshaft motor shaft bearing.

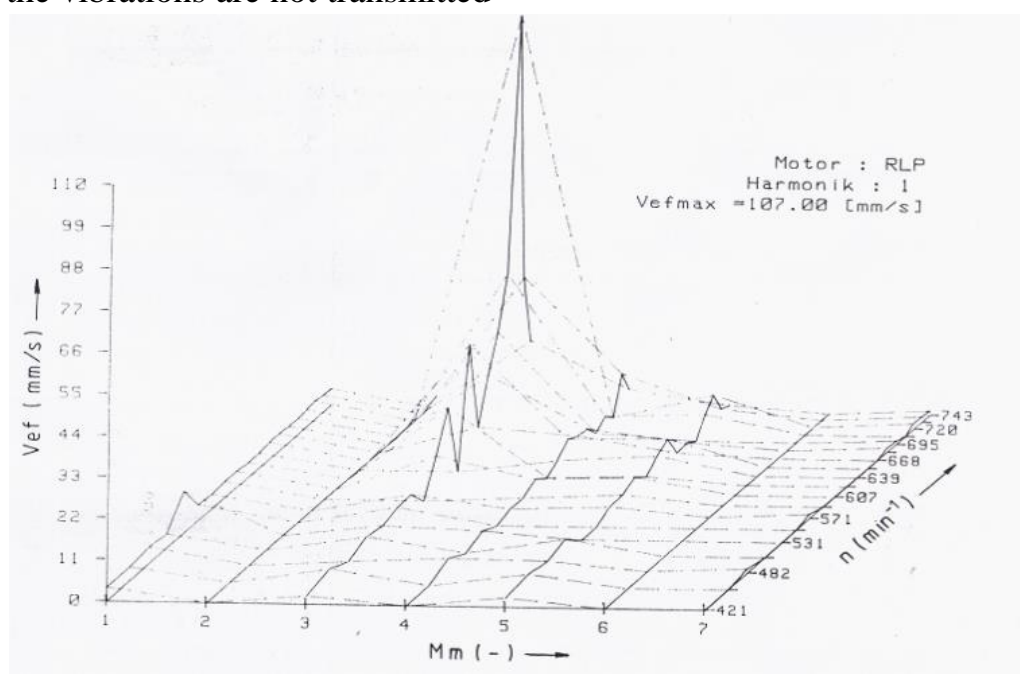

Figure 12 - Effective value of the vibration speed Vef $(\mathrm{mm} / \mathrm{s})$ for various measuring points on the engine at different speeds and engine loads

Figure 13 shows a change in the value $(0.5)$ of the Vef $(\mathrm{mm} / \mathrm{s})$ vibration sequence according to the bearing gap $(\mathrm{Z})$, at the measuring point 3 , the direction
$\mathrm{Xb1}$. The values of the gap $(\mathrm{Z})$ are determined according to the formula Fq. (4):

$$
Z=0.22 \cdot V e f^{2}+9.7 \cdot V e f+40.8 \pm s
$$




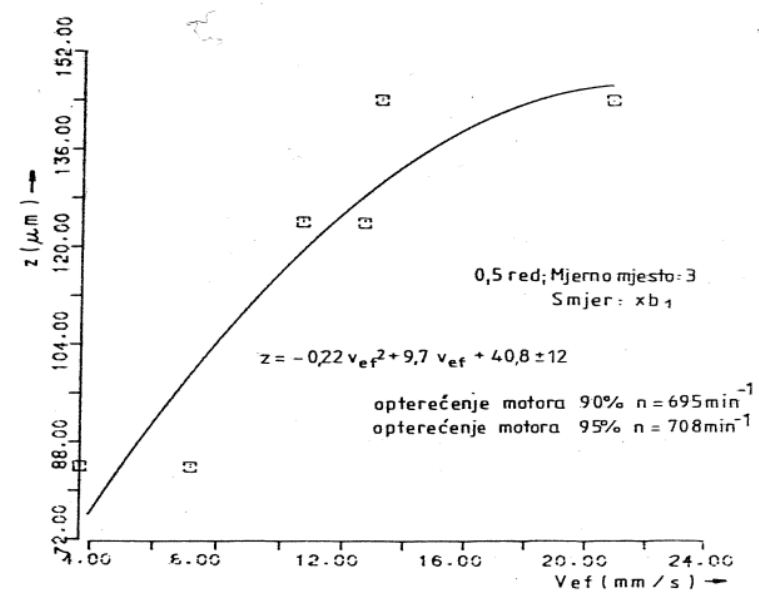

Figure 13 - Change in the effective vibration speed Vef $(\mathrm{mm} / \mathrm{s})$ depending on bearing clearance $(z)$

4. APPLICATION OF MODERN MONITORING SYSTEMS TO MACHINE AND ELECTRICAL INSTALLATIONS IN HYDROPOWER PLANTS

Monitoring systems have wide application capabilities. Provides fast and reliable measurement of the size of the wear (gap) in the sliding bearings and roller bearings, measurement of vibration parameters and powerful vibration analysis, special vibration methods for determining the technical correctness of the toothed assemblies - „Spectrum analasys“, speed measuremnt, lubricating oil temperature measurement or temperature of the coolant fluid, analysis of the lubricating oil, positioning of the upper dead center, in the case of internal combustion engines.

Because it is a multi-channel system, a large number of diagnostic parameters can be monitored and measured in machine and electrical installations in hydropower plants. In hydroelectric power plants, besides the hydro-aggregate, there are many other equipment, devices and systems that also perform technical diagnostics. On the basis of the measured values, the diagnostics of the technical condition of mechanical and electrical installations in hydro power plants is carried out.

Data on the degree of wear and damage of mechanical elements (gears, shaft and shaft sleeves, slip and roller bearings) are obtained, data on the imbalance is a very important parameter, in order to balance the system in accordance with the prescribed balancing standards.

The selected symptoms of failures mark the relevant frequency lines and create the size of the symptoms of the failures whose trend can be controlled. Alarm conditions can also be based on statistical estimates of the selected parameters. Figures $14-17$ show the most frequently used off-line monitoring systems of the various manufacturers. Figure 14 shows the device of Leonova SPM - Sweden.
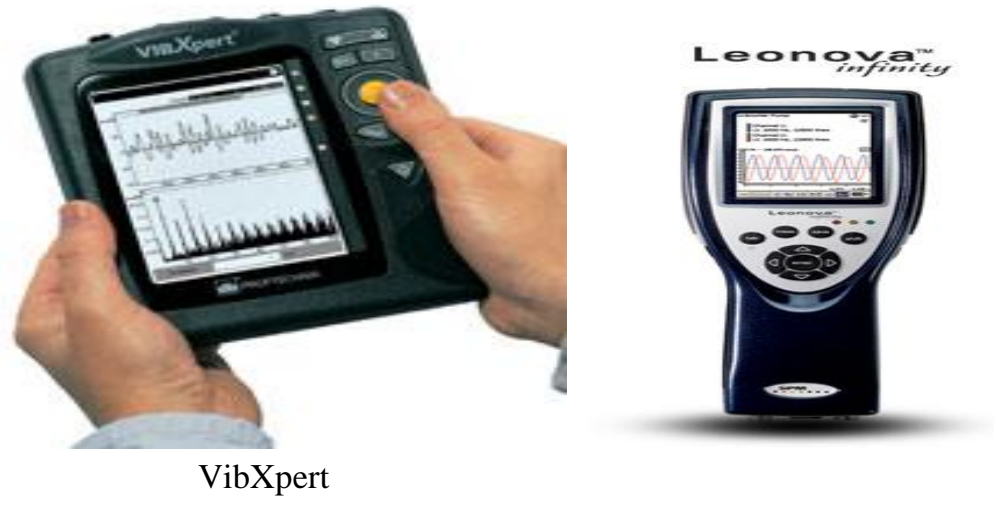

\section{Picture 14 - Leonova SPM - Sweden}

The device's operation is based on the method The Shock Pulse Method. This diagnostic method in relation to other procedures for rolling bearings diagnostics using vibration parameters differs in that the SPM procedures are based on analyzing the roller bearing as a generator of impact pulses rather than as a vibration generator. This means that shock pulses from the bearings appear at higher frequencies and can easily be detected in the first stage of the development of bearing damage.

The device can not be used for sliding bearing diathesis. 
Figure 15 shows the devices of the French company $01 \mathrm{Db}$ - AREVA, whose main activity is related to the diagnosis of nuclear power plants in France.
Devices are small in size, easy to carry, can snap into the pocket, have powerful performance that eases the daily work of the vibrodygnosticist.

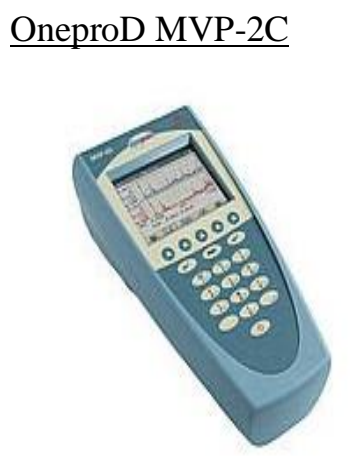

\section{OneproD MVP-2EX}

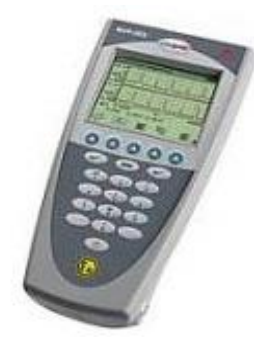

\section{$\underline{\text { Multivib }}$}

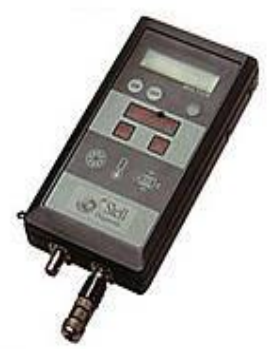

Figure 15 - Portable monitoring systems of the French company 01 Db-AREVA

The most used device in our premises is: OneproD MVP-2C: 2-channel portable vibration analyzer. The device enables easy monitoring of vibration levels as well as sophisticated analysis and diagnostics, data collector, on-site balancing, 2-channel vibration analyzer, digital recorder, line analysis in vibration spectra. And more. Special attention has been paid to

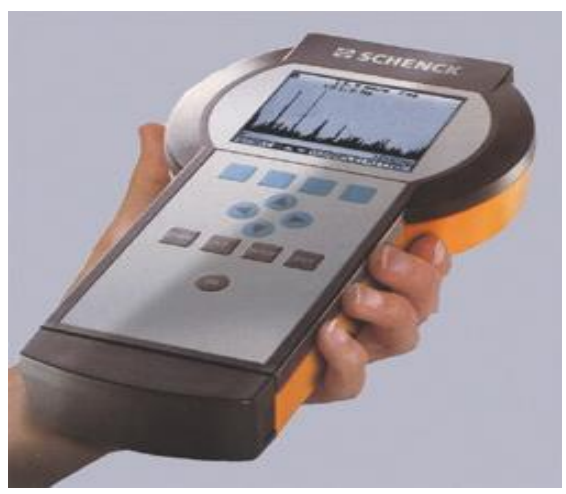

Figure 16 - The device of SKF-Microlog

For mechanical and electrical installations installed in the 1950s, a project for modernization and protection of the system against major failures, cancellations and non-compliance was made. The system display is given in Figure 18, [9].

The system of protection of the plant from disruptions from work and repairs is based on measurement and monitoring of a number of mechanical parameters of plant operation. The sizes measured and monitored are as follows:

- Level of vibration on bearings (Vrms),

- Critical temperature of bearings of the plant,

- The speed of the drive systems.

Based on these parameters, it is possible to directly or indirectly detect irregularities in the operation and protection of the plant from several possible faults. The protection system is designed to: reducing the time of acquisition and signal processing, thanks to the new processing algorithm and USB interface.

Today, MVP-2C is the fastest system on the market. Figures 16 and 17 show the devices of the Swedish company SKF and Danish firm Brule \& Kjaer.

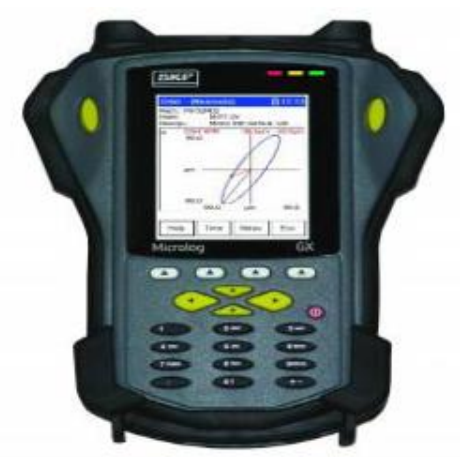

Figure 17 - The device of Brule \& Kjaer

- Prevents overheating of the system bearings and damage to the system.

- Detects the rotor of the rotor system and prevents operation in conditions of elevated vibration levels.

The system consists of a sensor and a measurement-acquisition subsystem that collects measurable data, compares them with the specified limit values and stores it in the database and the logical part of the system that decides on the inclusion of alarm and/or eventual shutdown of the plant. The stored data can be transferred from the $\mathrm{CD}$ card to the measuring system on a PC in Exel format. This configured system can be further hardware and software expanded as needed.

The system is designed and configured to send SMS messages about the state of the system to preprogrammed numbers in case of an alarm occurrence. 


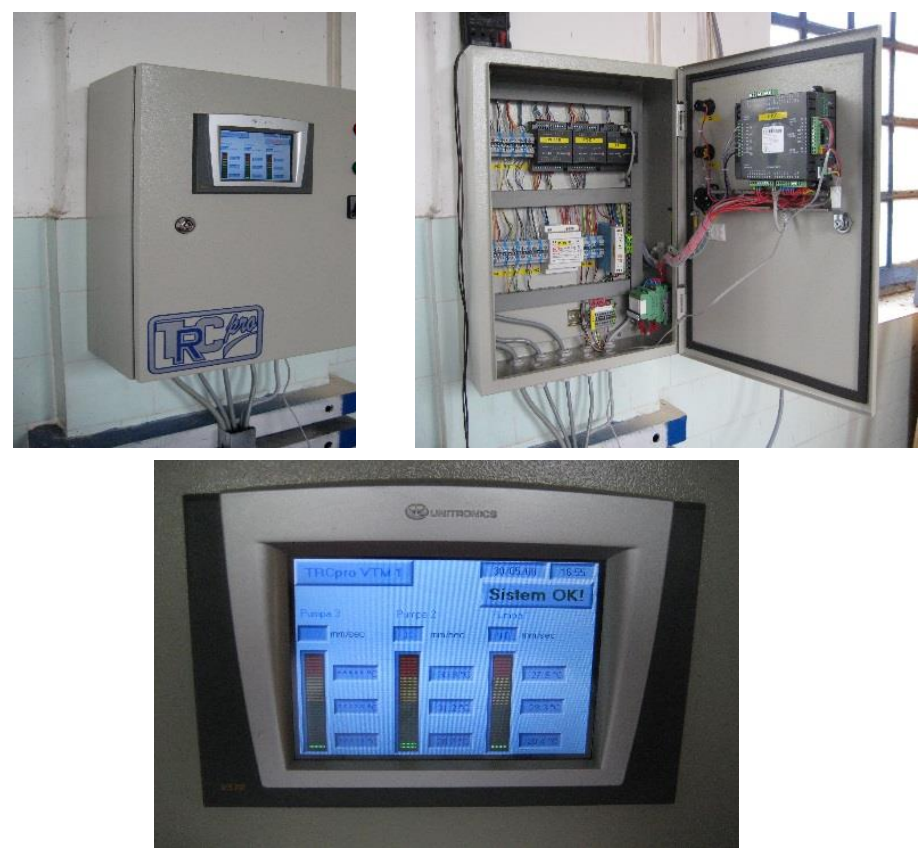

Figure 18 - Monitoring systems for machines and electrical installations that have long been in use (classic system implementation)

There are many quality OFF-LINE monitoring systems in the world. In addition to the application of modern monitoring systems, the author of this paper proposed preventive maintenance measures for many plant users. In periods of high water inflows in hydroelectric power plants, one part of the water goes underground roads below the foundations of the plant, on which are installed mechanical and electrical circuits, resulting in the collapse and cracking of the foundations, causing damage to the circuits. The user accepted the obligation to check the connections of the foundations on the foundations every six months [10].

Figure 19 shows the ON-LINE monitoring system of the French company $01 \mathrm{Db}-\mathrm{AREVA}$ at the hydropower plants [11].

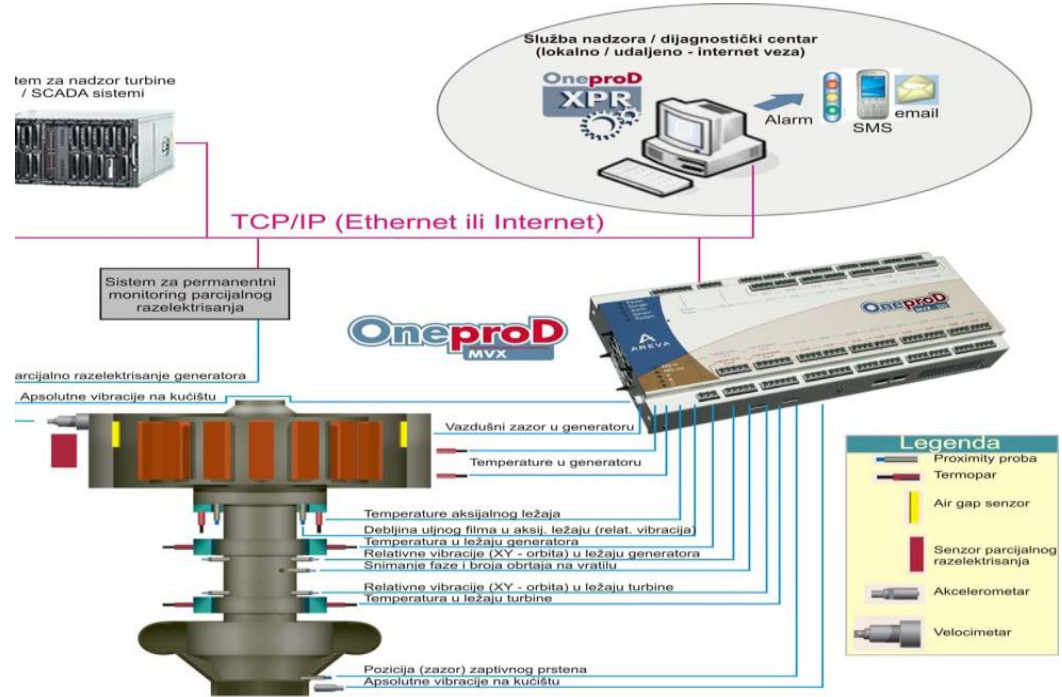

Figure 19 - Overview of the hydroaggregate monitoring system, standardly used sensors, OneproDMVX, diagnostic acquisition system and OneproD diagnostic software

Based on many years of experience in the field of the dynamic orbit of the sleeve in the sliding bearing. development, research, design and maintenance of mechanical and electrical installations, the author of the paper attaches great importance to the application of the monitoring system for determining the degree of wear of sliding bearings, based on the measurement of If it is a turbine system, it is compulsory to measure the dynamic orbit on the combined bearing of the turbine (radial - axial bearing), the radial bearing of the turbine and the generator bearing. The measurement of the relative vibrations of the rotary system is carried out. 
In addition to this system, the author has designed a special monitoring system that allows dynamic monitoring of the rotational system in the 3-D system, Figure 20 [12].

At one location during the operation of the hydroelectric power plant, a dynamic imbalance arose due to damage to the blades of the turbine turbine due to cavitation and the appearance of ,piting“ on the impeller, which caused the so-called: „escape the system " and the sudden wear of turbine bearings. The wear of the bearing was up to $20 \mathrm{~mm}$, followed by the friction of the turbine shaft sleeve on the steel sleeve of the sliding bearing.

The emergency intervention of the duty staff prevented the havaria. The repair of the damage has been completed successfully.

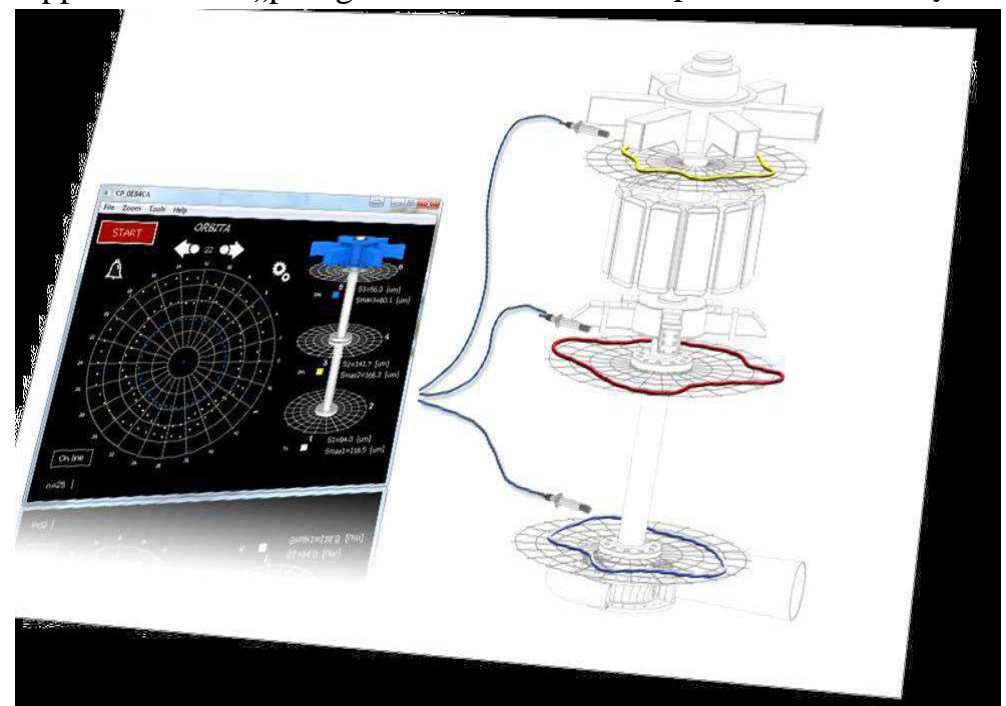

Figure 20 - Application of monitoring system for sliding bearings at hydroelectric power plants

Figure 21 shows the modern monitoring system for monitor two aggregates during operation or only one 2 mini hydro power plants. The power of each hydroelectric power plant is $100 \mathrm{KVA}$. The monitoring system is so designed that it can simultaneously aggregate, depending on the inflow of water in the hydroelectric power plant. The system was installed in Elektroprivreda Crne Gore [12], [13].

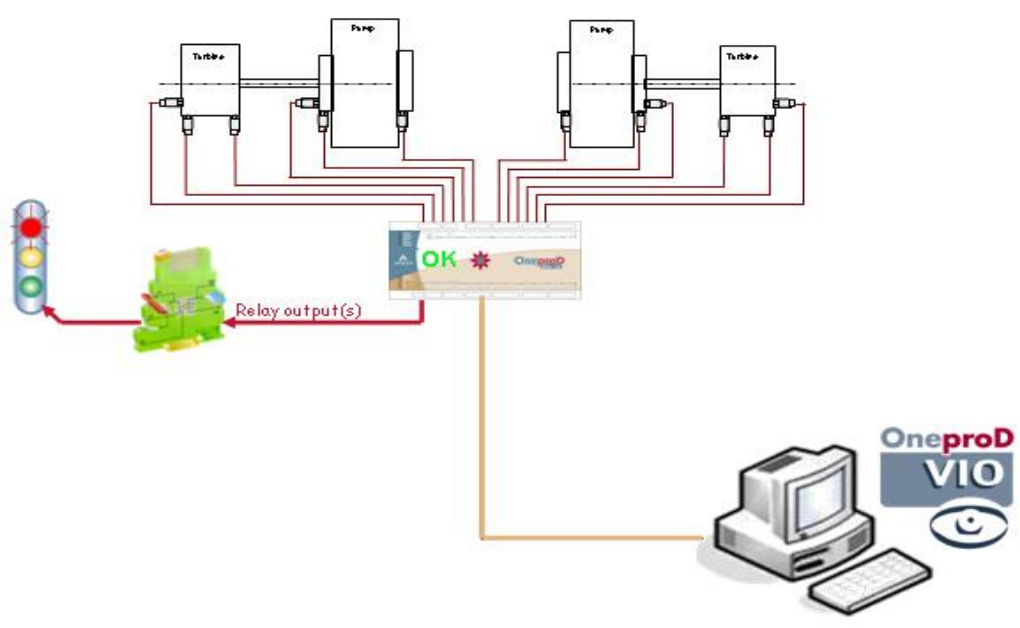

Figure 21 - Display of the monitoring system at mini hydro power plants

There are many quality ON-LINE monitoring systems in the world: Emerson (monitorig system installed in TPP Pljevlja), Bently Nevada (system installed in Višegrad HPP), Brule \& Kjaer (system installed in HPP Perućica) and other system manufacturers. The concept of: the minimum, standard and recommended monitoring system on the stands is presented. For mechanical and electrical installations that do not have
ON-LINE monitoring systems, periodic measurements of certain diagnostic sizes are recommended every 12 months or 15 months [11]. In the following section, diagnostic summaries are summarized in Tables 1, 2 and 3 [11]. The above tables contain a summary of the information of the vibrodygnostics of the plants. Vibrodiagnostics has found extremely high application in the technical diagnostics of the systems. 


\section{Table 1. System imbalance}

\begin{tabular}{|l|l|l|l|l|l|}
\hline Source of vibration & Existing vibration & $\begin{array}{l}\text { Dynamic } \\
\text { direction }\end{array}$ & Amplitude & $\begin{array}{l}\text { Characteristics of } \\
\text { the spectrum }\end{array}$ & Comments \\
\hline $\begin{array}{l}\text { Imbalance of mass: } \\
\text { static } 1 \mathrm{H} \text { radial *stable } \\
\text { narrow range }\end{array}$ & $\begin{array}{l}\text { Bending the rotor due to } \\
\text { thermal pressure can } \\
\text { cause amplitude } \\
\text { increase with } \\
\text { temperature }\end{array}$ & & & & \\
\hline Dynamic & $1 \mathrm{H}$ & radial & & general, some 1H \\
harmonics & $\begin{array}{l}\text { a much } \\
\text { generalized form } \\
\text { of adjustment }\end{array}$ \\
\hline Couple & $1 \mathrm{H}$ & radial, axial & & & \\
\hline Suspended rotor & $1 \mathrm{H}$ & axial, radial & & & \\
\hline
\end{tabular}

*Radial plane includes tangential directions in all parts.

$\mathrm{H}$ - denotes the order of the hormone in the vibration spectrum.

Table 2. System accuracy

\begin{tabular}{|l|l|l|l|l|l|}
\hline Source of vibration & Existing vibration & $\begin{array}{l}\text { The dominant } \\
\text { direction }\end{array}$ & Amplitude & $\begin{array}{l}\text { Characteristics } \\
\text { of the spectrum }\end{array}$ & Comments \\
\hline Angular nonsense & $1 \mathrm{H}, 2 \mathrm{H}$ & Axial & stable & narrow range & $\begin{array}{l}\text { Most of the divergences } \\
\text { are combinations of } \\
\text { angular and parallel }\end{array}$ \\
\hline Parallel insanity & $1 \mathrm{H}, 2 \mathrm{H}$ & Radial & stable & narrow range & $\begin{array}{l}\text { On long paired ranges, 1H } \\
\text { will be higher }\end{array}$ \\
\hline $\begin{array}{l}\text { Combination angle } \\
\text { and parallel }\end{array}$ & $1 \mathrm{H}, 2 \mathrm{H}$ & radially, axially & stable & narrow range & $\begin{array}{l}\text { Divinity also indicates } \\
\text { monochrome } 2 \mathrm{H}\end{array}$ \\
\hline $\begin{array}{l}\text { Stretch the bearing } \\
\text { a }\end{array}$ & $\begin{array}{l}1 \mathrm{H} \text { and tone bearing } \\
\text { tangential, axial }\end{array}$ & high stable & narrow range & $\begin{array}{l}\text { Usually connected with } \\
\text { axial components }\end{array}$ \\
\hline Insecure impeller & $\begin{array}{l}2 \mathrm{H} \text { grows in the } \\
\text { amount of blade } \\
\text { accordion }\end{array}$ & Radially & stable & narrow range & $\begin{array}{l}\text { Usually connected to } \\
\text { lower axial amplitudes }\end{array}$ \\
\hline
\end{tabular}

Table 3. Bended shaft - system shaft

\begin{tabular}{|l|l|l|l|l|l|}
\hline $\begin{array}{l}\text { Source of } \\
\text { vibration }\end{array}$ & $\begin{array}{l}\text { Existing } \\
\text { vibration }\end{array}$ & $\begin{array}{l}\text { The dominant } \\
\text { direction }\end{array}$ & Amplitude & $\begin{array}{l}\text { Characteristics of the } \\
\text { spectrum }\end{array}$ & Comments \\
\hline $\begin{array}{l}\text { Slightly bends } \\
\text { the shaft-shaft }\end{array}$ & $1 \mathrm{H}, 2 \mathrm{H}$ & $\begin{array}{l}\text { axially, radially, } \\
\text { tangentially }\end{array}$ & stable & narrow range & $\begin{array}{l}\text { The rotor weight of the rotor } \\
\text { occurs as an imbalance }\end{array}$ \\
\hline $\begin{array}{l}\text { Bent shaft-shaft } \\
\text { on couplings }\end{array}$ & $1 \mathrm{H}, 2 \mathrm{H}$ & $\begin{array}{l}\text { axially, radially, } \\
\text { tangentially }\end{array}$ & stable & $\begin{array}{l}\text { narrow range, } \\
\text { perhaps 2H or 3H } \\
\text { harmonics }\end{array}$ & $\begin{array}{l}\text { Coupling duration occurs as a } \\
\text { breakdown }\end{array}$ \\
\hline
\end{tabular}

\section{APPLICATION OF MODERN MONITORING SYSTEMS ON MECHANICAL AND ELECTRI- CAL PLANTS IN THERMAL POWER PLANTS}

The testing of the technical correctness of the plants in thermal power plants is a complex analysis of the construction parameters, conditions of exploitation and maintenance, the history of drive events, the operating regime, the results of periodic and continuous testing (including the factory), interventions and visual inspections. Figure 22 shows the thermoelectric structure of coal [14].

Monitoring system on thermal power plants depends on the construction of the plant and the request of the end user who wants the level of monitoring of the system to install.

Below is an example of the request of the contracting authority in the public tender, for the installation of the monitoring system. 


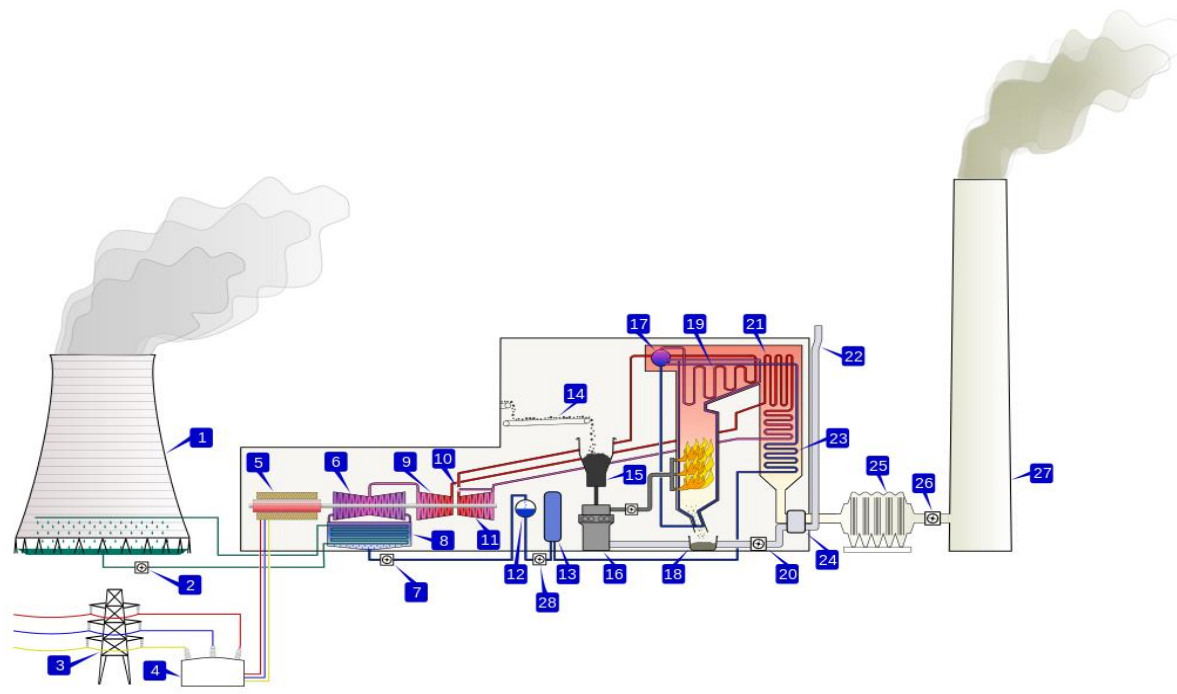

\section{Figure 22 - Typical display of thermal power plant operation on coal}

The request shall require the contractor to deliver and install the measuring equipment which shall provide the following:

- Measurement the speed of the servomotor of the turbine control valves,

- Measurement of the turbocharging speed (with a turbine cursor),

- Measurement of the distortion (eccentricity) of the rotor,

- Measurement of the axial (axial) rotation of the rotor - 2nd component,

- Measurement of relative propagation of rotor CVP, CSP, CNP - 3 sets,

- Measurement of the thermal expansion of the CVP and CSP-2 enclosure,

- Measurement of absolute vibrations in the bearing assembly of the turbo-generator sets.

The Bidder must deliver a complete measuring system consisting of:

- Central control units, power supply units and required number of modules,

- Sensors, sensor brackets, connecting boxes and required cable accessories,

- Cables for connecting the complete system.

The system manufacturer must be certified according to the ISO 9001 standard. The central control unit is placed in a special cabinet that is mounted in a thermal power plant with a supply voltage of $220 \pm 15 \mathrm{~V}$, $50 \mathrm{~Hz}$ and a redundant $24 \mathrm{~V} \mathrm{DC}$ and the required number of expandable modules in order to ensure the upgrade system.

With the offer, provide the types and technical characteristics of the offered equipment, references for equipment and references of your company for this type of work.
Similar results are measured for diagnostic parameters such as hydroelectric power plants and other mechanical and electrical installations. Because of the workload it will not be displayed. Based on the submitted request for the procurement and installation of the monitoring system, it can be concluded that the job is very demanding and responsible.

The equipment that is installed is very expensive, but if you take into account that the value of the thermal power plant reaches the value of several hundred million euros, it is certainly that this business is economically justified.

\section{CONCLUSION}

The application of modern monitoring systems and technical diagnostic methods can be reliably determined when and where the problem will arise in further exploitation of the plant, assess how the system will continue to function over time, predict the causes of faults and how to eliminate them, predict the time to delay or failure of the system.

Modern methods of technical diagnostics based on measurement of mechanical and electrical quantities and their analysis enable the support of sensors of different purposes and various manufacturers. The possibilities of a very advanced software configuration of the diagnostic and monitoring system are provided. Measured and software-processed values of parameters as well as their limit values and alarms are displayed in various ways. They have the possibility of remote control and monitoring, disconnecting the drive from use in order to prevent damage and damage to the system.

High accuracy of measurement of all measuring sizes is ensured, on the basis of which the technical correctness of the plant can be determined in potency. 
Multichannel, modular, software-hardware syste$\mathrm{ms}$ for monitoring, control and protection, optimize the operation of the plant. It is widely used in all technical areas: internal combustion engines, hydroelectric power plants, power plants, process plants and many other areas. Different monitoring systems (device and equipment compatibility) of various manufacturers are supported. Mechanical and electrical power plants that are in the rotary and continuous system are very important.

The author of the paper gives special attention to the diagnosis of sliding and roller bearings, which depends on the basic functioning of the plant. The new method of diagnostics of sliding bearing leakage by measuring the dynamic orbit of the sleeve in the bed does not depend on the type of plant, applies to all types of internal combustion engines and other plants. Users' equipment suggests that this part of the monitoring system be installed in plant maintenance systems.

In the past, many important systems did not have built-in monitoring systems, and many problems were created.

For installations that have been in use since the 1950s, simpler monitoring systems for monitoring basic functions have been designed. Alarm systems can be light or sound, or in the form of SMS notifications.

The field of technical diagnostics is a very interesting area for many scientists. The area is underexplored as well as in hospitals diagnostics.

\section{REFERENCES}

[1] Žegarac N, Dijagnostika kliznih ležajeva u dizel motorima. Doktorska disertacija, Fakultet strojarstva i brodogradnje, Sveučilište u Zagrebu, 1989.

[2] Tehnička dokumentacija američke firme Cummins, Beograd, 2010.

[3] Žegarac N, Postupak i uređaj za određivanje zazora u kliznim ležajevima, merenjem dinamičke putanje glavnih rukavaca kolenastog vratila motora sa unutrašnjim sagorevanjem, Patent br. 48216-P-
640/93, Zavod za inetelektualnu svojinu u Beogradu, 1993.

[4] Tehnička dokumentacija švicarske firme Sulzer, Karlovac, 1980.

[5] Tehnička dokumentacija francuske firme SEMT Pielstick, Karlovac, 1988.

[6] Žegarac N, Monitoring sistem za klizne ležajeve, Bilten SAIN, Beograd, 2004.

[7] Černej A. i dr. Radni uslovi podmazivanja ležaja dizel motora, Goriva i maziva 36 (5-6) 229-236, 1984.

[8] Žegarac N, Idejni projektat monitornig sistema za klizne ležaje pre startovanja sistema u pogon, Bilten SAIN, Beograd, 2015.

[9] Ličen H, Zuber N, Žegarac N, Monitoring sistem Tehničko razvoni centrar - TRCpro-Novi Sad, 2010.

[10]Žegarac N, Unapređenje sistema tehničkog održavanja mini hidroelektrana, analiza uzroka nespravnosti, kvarova, otkaza u radu i havarija, Vojnotehniči glasnik br. 4, Beograd, 2017.

[11]Ličen H, Zuber N, Proaktivno održavanje hidroturbinske opreme primenom 01 Db-MetrovibOnepro koncepta, Tehnička dijagnostika, br. 1/2008, Beograd, 2008.

[12]Žegarac N, Novi projekat monitoringa kliznih ležaja, Bilten SAIN, Beograd, 2013.

[13]Žegarac N, Aplication of modern monitoring systems in mini hidropower plants, Mllitary Technical Courier, Vol. 64, br.4, pp 1102-1116, October - December, 2016.

[14]Milovanović Z, O termoenergetskim postrojenjima za proizvodnju energije, Elektrotehnički fakultet, Univerzitet Banja Luka, 1980.

[15]Tehnička dokumentacija danske firme Bruel \& Kjaer, 2002.

[16]Tehnička dokumentacija švedske firme SKF, 2004.

[17]Tehnička dokumentacija švedske firme LeonovaSPM, 2008. 


\section{REZIME}

\section{PRIMENA SAVREMENIH DIJAGNOSTIČKIH SISTEMA NA MAŠINSKIM I ELEKTRO POSTROJENJIMA}

U radu je prikazana primena savremenih dijagnostičkih sistema na mašinskim i elektro postrojenjima, sa posebnim osvrtom i iskustvima u primjeni novog načina održavanja sistema i sprečavanja otkaza, nepravilnog rada $i$ havarije sistema. Krajnjim korisnicima se nude široke mogućnosti primene dijagnostičkih sistema, koji funkcionišu na principu OFF-LINE ili ON-LINE monitoring sistema. Primena novih sistema omogućuje korisnicima da obezbede ispravan rad u toku eksplaoatacije postrojenja. Značajno se povećava pouzdanaost sistema. Postižu se velike uštede u troškovima održavanja i eksploataciji postrojenja.

Ključne reči: savremeni dijagnostički sistemi, monitoring sistemi, elektronika, mašinska postrojenja, elektro postrojenja, dijagnostčiči parametri, dijagnostičke metode. 